\title{
Protective effect of ascorbic acid against fenvalerate induced toxicity in air-breathing fish Clarias batrachus
}

\author{
Sanjay Kumar Jigyasu \\ Department of Zoology, Patna University, Patna (Bihar), India \\ Dilip Kumar Paul* \\ Department of Zoology, Patna University, Patna (Bihar), India \\ *Corresponding author. E mail: dkpaul.pat31@gmail.com
}

\author{
Article Info \\ https://doi.org/10.31018/ \\ jans.v12i3.2320 \\ Received: July 15, 2020 \\ Revised: August 18, 2020 \\ Accepted: August 23, 2020
}

\section{How to Cite}

Jigyasu, S. K. and Paul, D.K. (2020). Protective effect of ascorbic acid against fenvalerate induced toxicity in air-breathing fish Clarias batrachus. Journal of Applied and Natural Science, 12(3): 380 - 387.https://doi.org/10.31018/jans.v12i3.2320

\begin{abstract}
The food demand in recent times has increased many folds. In order to augment the need for food, the agriculture practice is extensively carried out by the farmers and pesticides are widely used by them for the better yield of crops. Fishes are also cultivated by these farmers, and humans are consuming the fishes as they are very high nutritious food product. But, these pesticides through agricultural runoffs are contaminating the ponds as well the aquatic fauna like fish. The present research work deals with the evaluation of the protective effect of ascorbic acid on fenvalerate induced nephrotoxicity in Clarias batrachus. The pyrethroid pesticide- Fenvalerate EC $20 \%$ was administered directly in the water contained in the aquarium at the dose of 0.027 ppm, $0.042 \mathrm{ppm}$ and $0.083 \mathrm{ppm}$ respectively for $96 \mathrm{hrs}$ hours after the dose calculation through LC $_{50}$. Thereafter, ascorbic acid was administered orally by gastric intubation method at the dose of $200 \mathrm{mg} / \mathrm{Kg}$ body weight per day for 04 days to each pesticide treated group. The study revealed that, after the exposure of fenvalerate, there was significant damage at the biochemical levels like urea, creatinine, protein and albumin and histopathological study of kidney tissue in fish $C$. batrachus. But, after the administration of ascorbic acid, there was a significant restoration in the biochemical levels and in histopathology of the kidney of fish. The study concluded that Ascorbic acid possessed protective effect against fenvalerate induced toxicity in C. batrachus.
\end{abstract}

Keywords: Ascorbic acid, Biochemical assay, Fenvalerate, Histopathological study

\section{INTRODUCTION}

India is an agriculture-based country with the cultivation of all types of crops. For the better yield of crops, farmers are extensively using the pesticides. This has led to the entry of these agrochemicals in the human food chain. Apart from this, the humans are also consuming fish products because of its high nutritious value. These fishes are cultivated in the ponds which are near the agricultural fields. This has caused the migration of agrochemicals into the ponds by agricultural runoffs contaminating the aquatic fauna of the ponds. These fishes if consumed by humans, can cause serious health hazards. Organochlorine pesticides are known to cause more damage than organophosphates. But, in recent times the synthetic pyrethroids are known to be much safer and eco-friendly as they have the least toxicity to other animals but selective toxicity to insects. Fenvalerate is compatible with many other pesticides, plant growth regulators and micronutrients. But, causes the least toxicity to humans but possesses very high insecticidal activity (Coats et al., 1989; Tripathi, 1992; Elbert et al., 2005; Bretschneider et al., 2007).

Fenvalerate is a pyrethroid group of pesticide and is highly neurotoxic to the insects which damage the sodium channels. Moreover, the neurotransmission is severely disrupted especially the gamma-aminobutyric acid receptors and ATPase pathways (Clark and Matsumura 1982; Matsumura 1983; Narahashi, 1983; Cole et al., 1984; Eells et al., 1993; Zhang et al., 2017; Awoyemi et al., 2019). The extensive use of pesticides has led to the accumulation of these in the fish muscles as well as its vital tissues. The impact of fenvalerate on fish metabolism has been carried out by a plethora of researchers (Lee et al., 1985, Tripathi, 1992; Tripathi and Verma, 2004; Velmurugan et al., 2007; Ma et al., 2009, Jigyasu and Paul 2016).

In recent times, researchers have focussed their work on the development of antidotes against the pesticideinduced toxicity in fish. This not only controls the prob- 
lem but also enhances the protein quality and immunity of the fish (Datta-Mitra and Ahmed 2014; Awad and Awad 2017; Vallejos et al., 2016; Nhu et al., 2019). Ascorbic acid, also known as Vitamin $\mathrm{C}$ is a natural water-soluble vitamin with potent antioxidant, antibacterial, antitoxic, immune-booster and many other activities which are helpful in the metabolic functions of the body. They are exclusively found in the citrus fruits, vegetables etc. (Merlevede 1950; Fujimoto et al., 2013). Hence, ascorbic acid has proven very promising role to control the disease in pesticide-induced toxicity (Bhattacharya and Kaviraj 2009). The objective of the present study was to evaluate the toxic impact of fenvalerate, a commonly used insecticide on biochemical (Kidney Function Tests) parameters and histopathological study of an air-breathing fish Clarias batrachus and to find the ameliorating effect of ascorbic acid against fenvalerate induced toxicity.

\section{MATERIALS AND METHODS}

Animals: The experiment was carried out in the Department of Zoology, Patna University, Patna, Bihar, India. The ethical approval was obtained from the Post Graduate Research Council of Patna University, Patna, Bihar. Live specimens of $C$. batrachus were procured from the local market of Patna, Bihar (India) and were acclimatized in the laboratory before experimentation. The fishes were captivated in large aquaria with 50 gallon water capacity. The fishes were fed with traditional lab food as chopped goat liver and earthworms. The experimental animals were taken care throughout the experimental period so as to keep them healthy and free from parasites.

Test chemical: In the present study, Fenvalerate 20\% (Isagro-Asia, Gujarat, India) was procured from the local market of Patna, Bihar, India. Fenvalerate was administered directly in water contained in three aquariums with the different doses of Fenvalerate 0.027 ppm, $0.042 \mathrm{ppm}$ and $0.083 \mathrm{ppm}$ respectively after the dose calculation through $\mathrm{LC}_{50}(2.75 \mathrm{ppm})$.

Preparation of dose of ascorbic acid: Ascorbic acid (Celin-500 mg) from Galaxo Company was used and $200 \mathrm{mg} / \mathrm{kg}$ b.w. was calculated as maximum permissible dose after $L_{50}$ calculation. The dose was administered by gastric intubation method to the fishes (Vale and Kulig 2004).

Study groups and sampling: The control group of fish received no treatment. The 'treatment' groups received fenvalerate at the dose of $0.027 \mathrm{ppm}, 0.042$ ppm and $0.083 \mathrm{ppm}$ for $96 \mathrm{hrs}$ in the respective aquariums. Upon all the three fenvalerate treated groups, Ascorbic at the dose of $200 \mathrm{mg} / \mathrm{Kg}$ body weight was administered to the respective groups of aquariums for 04 days by gastric intubation method to the fishes.

Biochemical evaluation: For the biochemical study, serum from the fish blood was extracted and tests were carried out. In this study, the serum urea levels (Berthelot, 1859), serum creatinine levels (Bonsnes 1945), serum protein levels (Gornall et al., 1949) and albumin levels (Doumas et al., 1971) were evaluated.

Histopathological evaluation: For the histopathological study, kidney tissues were dissected and collected from all the group of sacrificed fishes. The tissues were washed in $0.65 \%$ normal saline, grossed into small pieces and finally fixed in $10 \%$ neutral formalin for 24 hours. Thereafter, tissues were dehydrated through the process of graded series of ethanol and finally embedded into paraffin. Thin sections of $5 \mu \mathrm{m}$ thickness were sliced through rotary microtome and stained with haematoxylin and eosin (H\&E) for the histopathological study under light microscope (Gamble 2008).

Statistical analysis: The results are presented as mean $\pm S D$, and the total variation present in a set of data was analysed through one-way analysis of variance (ANOVA). The difference among mean values has been analysed by applying Dunnett's test. Calculations were performed with the Graph Pad Prism Program (Graph Pad Software, Inc., San Diego, U.S.A.). The criterion for statistical significance was set at $P<0.05$.

\section{RESULTS}

Biochemical evaluation: In the present study, there was significant $(p<0.0001)$ increase in the levels of serum urea in control as $16.67 \pm 0.9545$, fenvalerate $0.027 \mathrm{ppm}$ treated as $59.93 \pm 2.442$ with significant $(p<0.0001)$ normalisation in ascorbic acid $200 \mathrm{mg} / \mathrm{kg}$ b.w treated group as $29.83 \pm 2.469$, fenvalerate $0.042 \mathrm{ppm}$ treated as $48.0 \pm 1.844$ with significant $(p<0.0001)$ normalisation in ascorbic acid $200 \mathrm{mg} / \mathrm{kg}$ b.w. treated group as $40.17 \pm 2.301$, fenvalerate $0.083 p p m$ treated as $43.67 \pm 1.542$ with significant normalisation in ascorbic acid $200 \mathrm{mg} / \mathrm{kg} \mathrm{b.w}$. treated as 29.83 \pm 2.469 (Fig. 1)

In serum creatinine analysis the level in control was $0.766 \pm 0.032$ fenvalerate $0.027 \mathrm{ppm}$ treated was $1.992 \pm 0.075$ with significant $(p<0.0001)$ normalisation in ascorbic acid $200 \mathrm{mg} / \mathrm{kg}$ b.w treated group was $0.916 \pm 0.035$, fenvalerate $0.042 \mathrm{ppm}$ treated was $1.475 \pm 0.038$ with significant normalisation $(p<0.05)$ in ascorbic acid $200 \mathrm{mg} / \mathrm{kg}$ b.w. treated group was $1.033 \pm 0.057$, fenvalerate $0.083 \mathrm{ppm}$ treated was $1.275 \pm 0.038$ with significant $(p<0.0001)$ normalisation in ascorbic acid $200 \mathrm{mg} / \mathrm{kg}$ b.w. treated was $1.133 \pm 0.062$ (Fig. 2).

In serum protein analysis, the level in control was $4.383 \pm 0.185$ fenvalerate $0.027 \mathrm{ppm}$ treated was $13.43 \pm 0.639$ with significant $(p<0.05)$ normalisation in ascorbic acid $200 \mathrm{mg} / \mathrm{kg}$ b.w. treated group was $6.317 \pm 0.235$, fenvalerate $0.042 \mathrm{ppm}$ treated was 


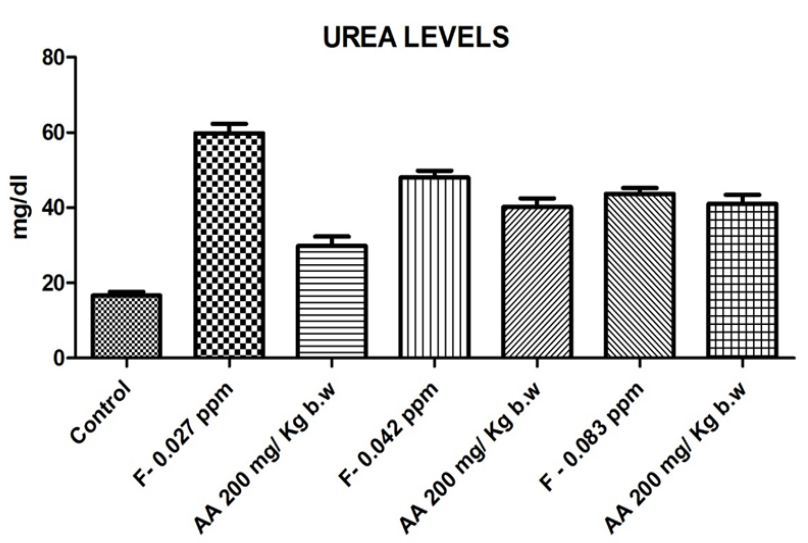

Fig. 1. Effect of ascorbic acid (AA) on fenvalerate (F) induced toxicity showing serum urea levels in comparison to control. [Fenvalerate- $0.027 \mathrm{ppm}, 0.042 \mathrm{ppm}$ and $0.083 \mathrm{ppm}$ respectively] ( $n=6$, values are mean \pm S.D).

\section{PROTEIN LEVELS}

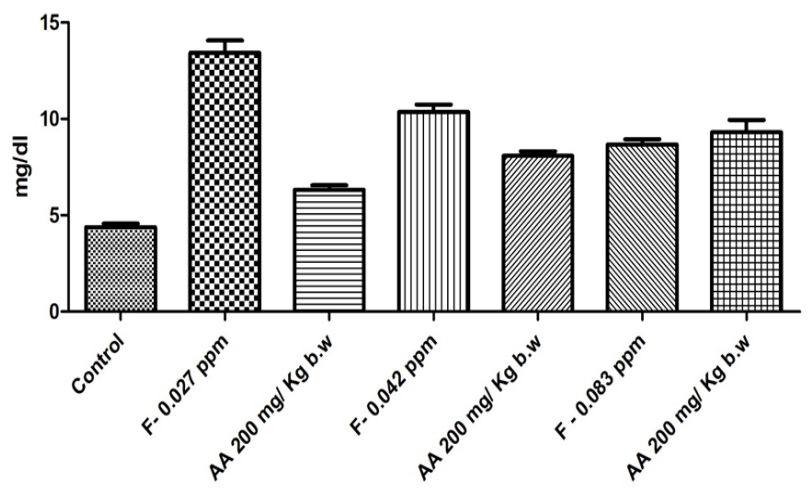

Fig. 3. Effect of ascorbic acid (AA) on fenvalerate (F) induced toxicity showing serum protein levels in comparison to control. [Fenvalerate- $0.027 \mathrm{ppm}, 0.042 \mathrm{ppm}$ and 0.083 ppm respectively] ( $n=6$, values are mean \pm S.D).

$10.37 \pm 0.378$ with significant $(p<0.0001)$ normalisation in ascorbic acid $200 \mathrm{mg} / \mathrm{kg}$ b.w treated group was $8.083 \pm 0.2301$, fenvalerate $0.083 \mathrm{ppm}$ treated was $8.667 \pm 0.272$ with significant $(p<0.05)$ normalisation in ascorbic acid $200 \mathrm{mg} / \mathrm{kg}$ b.w treated was $9.30 \pm 0.642$ (Fig. 3).

In serum albumin analysis, the level in control was $2.200 \pm 0.110$ fenvalerate $0.027 \mathrm{ppm}$ treated was $6.775 \pm 0.217$ with significant $(p<0.0001)$ normalisation in ascorbic acid $200 \mathrm{mg} / \mathrm{kg}$ b.w treated group was $2.800 \pm 0.125$, fenvalerate $0.042 \mathrm{ppm}$ treated was $5.00 \pm 0.226$ with significant $(p<0.0001)$ normalisation in ascorbic acid $200 \mathrm{mg} / \mathrm{kg}$ b.w treated group was $3.458 \pm 0.204$, fenvalerate $0.083 \mathrm{ppm}$ treated was $4.117 \pm 0.331$ with significant $(p<0.0001)$ normalisation in ascorbic acid $200 \mathrm{mg} / \mathrm{kg}$ b.w treated was $3.730 \pm 0.139$ in (Fig. 4).

Histopathological evaluation: The control section of the kidney showed normal architecture of nephrocytes

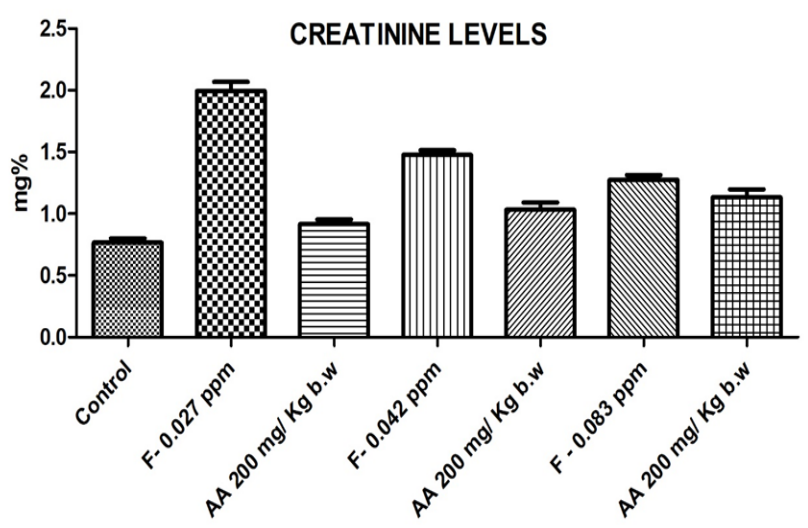

Fig. 2. Effect of ascorbic acid (AA) on fenvalerate (F) induced toxicity showing serum creatinine levels in comparison to control. [Fenvalerate- $0.027 \mathrm{ppm}, 0.042 \mathrm{ppm}$ and $0.083 \mathrm{ppm}$ respectively] ( $n=6$, values are mean \pm S.D).

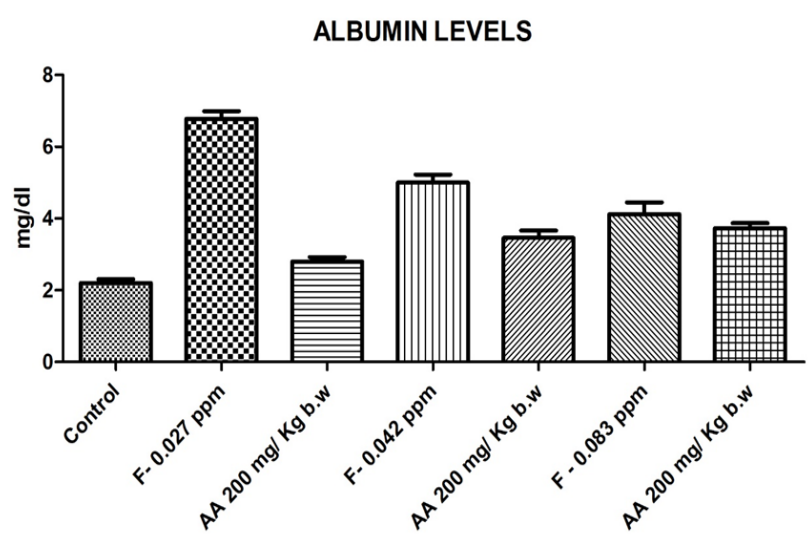

Fig. 4. Effect of ascorbic acid (AA) on fenvalerate (F) induced toxicity showing Serum albumin levels in comparison to control. [Fenvalerate- $0.027 \mathrm{ppm}, 0.042 \mathrm{ppm}$ and 0.083 ppm respectively] ( $n=6$, values are mean $\pm S . D$ ).

with Bowman's capsule and glomerulus. The convoluted and distal tubule architecture was quite normal denotes the normal physiological function of the nephrocytes (Fig. 5a. 1,2,3,4). In the Fenvalerate $0.027 \mathrm{ppm}$ treated the section, showed abnormal architecture of nephrocytes with degeneration in the Bowman's capsule and glomerulus. The convoluted and distal tubules were also highly degenerated as the rupture in the epithelial membrane were clearly observed (Fig. 5b. 1,2,3,4). But after, ascorbic acidtreated upon 0.027 Fenvalerate exposed group, there was significant normalisation in the architecture of nephrocytes, glomerulus, Bowman's capsule, convoluted and distal tubules. (Fig. 5c. 1,2,3,4). In the Fenvalerate $0.042 \mathrm{ppm}$ treated group, there was an observation of abnormal architecture of nephrocytes with a high degree of degeneration in the Bowman's capsule and glomerulus with the convoluted and distal tubules highly degenerated as the rupture in the epi- 
Jigyasu, S. K. and Paul, D.K. / J. Appl. \& Nat. Sci. 12(3): 380 - 387 (2020)
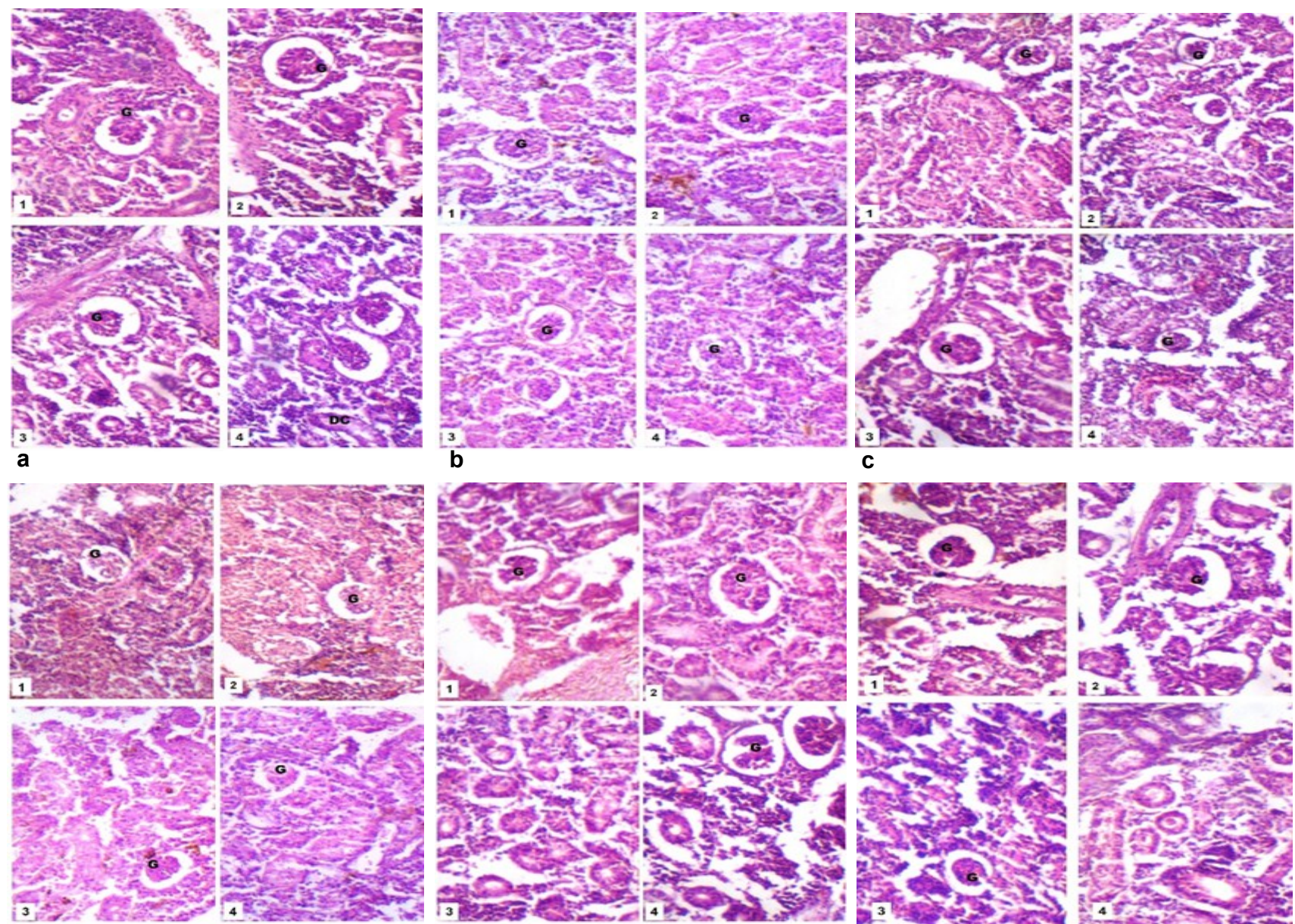
C

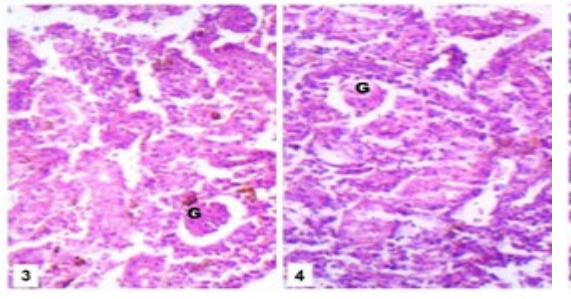
d
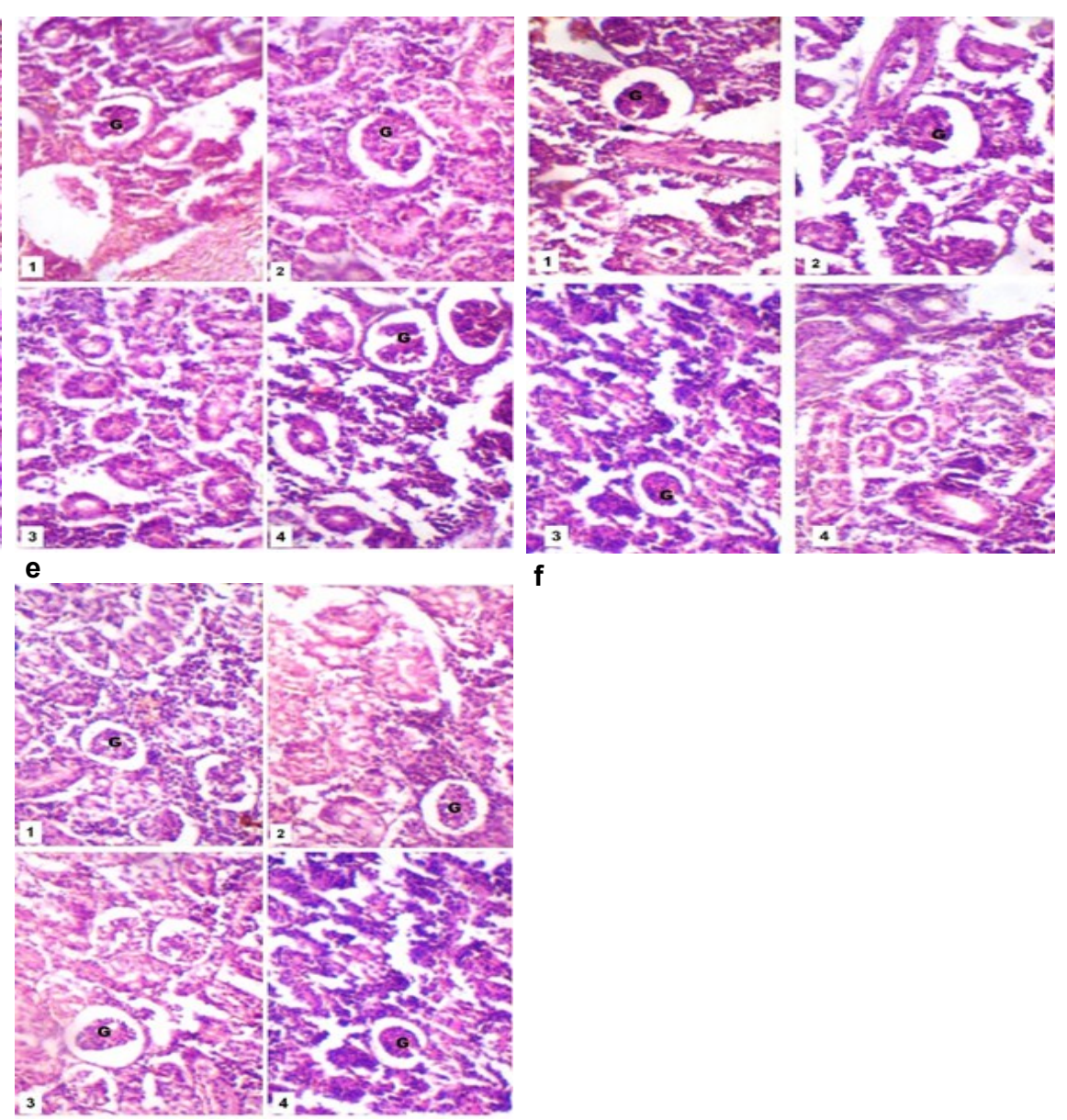
$\mathbf{f}$

g

Fig. 5. Section of kidney of C. batrachus: a (1 to 4) Control group showing normal architecture of nephrocytes with Bowman's capsule and glomerulus. x500. b (1 to 4) Fenvalerate 0.027 ppm showing the abnormal architecture of nephrocytes with degeneration in the Bowman's capsule and glomerulus along with the convoluted and distal tubules. x500. $c$ (1 to 4) Ascorbic acid treated upon 0.027ppm fenvalerate exposed group there showing significant normalisation in the architecture of nephrocytes, glomerulus, Bowman's capsule, convoluted and distal tubules. x500. $d$ (1 to 4) Fenvalerate 0.042 ppm showing high degree of degeneration in the Bowman's capsule and glomerulus with the convoluted and distal tubules highly degenerated as the rupture in the epithelial membrane can be seen. x500. e (1to4) Ascorbic acid treated upon 0.042 Fenvalerate exposed group showing significant normalisation in the nephrocytes especially in the Bowman's capsule and glomerulus. x500. e (1 to 4) Fenvalerate 0.083ppm treated group there is severe damage observed in the nephrocytes along with Bowman's capsule. x500. $g$ (1 to 4) Ascorbic acid treated upon 0.083 Fenvalerate exposed group showing significant normalisation in the nephrocytes especially in the Bowman's capsule, glomerulus convoluted and distal tubules denotes the normal functioning of the kidney. $x 500$. 
thelial membrane were clearly observed (Fig. $5 \mathrm{~d}$. $1,2,3,4)$. But after ascorbic acid treated upon 0.042 Fenvalerate exposed group showed significant normalisation in the nephrocytes especially in the Bowman's capsule and glomerulus. (Fig. 5e. 1,2,3,4). In Fenvalerate $0.083 \mathrm{ppm}$ treated group there was severe damage observed in the nephrocytes along with Bowman's capsule and glomerulus especially the convoluted and distal tubules were highly degenerated as the rupture in the epithelial membrane were clearly observed (Fig. 5f. 1,2,3,4). But after Ascorbic acid treated upon 0.083 Fenvalerate exposed group there was significant normalisation in the nephrocytes especially in the Bowman's capsule, glomerulus convoluted and distal tubules denoted the normal function of the kidney (Fig. 5g. 1,2,3,4).

\section{DISCUSSION}

In recent times, due to excessive utilisation of pesticides for the better yield of crops has caused illeffects to the aquatic ecosystem. The biomagnification of these pesticides through various food chains has reached the human food chain causing them various types of metabolic disorders as well as disease in them. The disease burden in the long duration of exposure is the cause of cancer as well (Katagi 2010; Hu et al., 2017; Clasen et al., 2018; Sabarwal et al., 2018; Mojiri et al., 2020; Yang et al., 2020). In the aquatic ecosystem, fishes are the best indicators of the toxicant exposure; hence the biochemical and histopathological parameters are the best to evaluate the pesticide toxicity (Sharma and Singh 2004 \& 2006; Ramesh et al., 2014; Woo et al., 2018; Bojarski and Witeska 2020).

In the present study, the kidney function test of the fenvalerate exposed air-breathing fish $C$. batrachus showed that the exposure of fenvalerate on three different doses- 0.023ppm, 0.042ppm and 0.083ppm caused a severe deleterious effect on the biochemical parameters as there was significant $(p<0.0001)$ rise in the urea $(59.93 \pm 2.442,48.0 \pm 1.844$ and $43.67 \pm 1.542$ respectively), creatinine $(p<0.0001) \quad(1.992 \pm 0.075$, $1.475 \pm 0.038$ and $1.275 \pm 0.038$ respectively), protein $(p<0.05)(13.43 \pm 0.639,10.37 \pm 0.378$ and $8.667 \pm 0.272$ respectively) and albumin levels. (6.775 \pm 0.217 , $5.00 \pm 0.226$ and $4.117 \pm 0.331$ respectively) But, after the administration of ascorbic acid there was significant $(p<0.0001)$ normalisation in the levels as in the urea $\quad(p<0.0001) \quad(29.83 \pm 2.469, \quad 40.17 \pm 2.301$ and $29.83 \pm 2.469$ respectively), creatinine $(p<0.0001)$ $(0.916 \pm 0.035,1.033 \pm 0.057$ and $1.133 \pm 0.062$ respectively), protein $(p<0.05) \quad(6.317 \pm 0.235,8.083 \pm 0.2301$ and $9.30 \pm 0.642$ respectively) and albumin $(p<0.0001)$ levels $(2.800 \pm 0.125,3.458 \pm 0.204$ and $3.730 \pm 0.139$ respectively).
Among the possible target organs, fenvalerate causes serious damage to the vital organs like liver and kidney as they are the most vulnerable part. Most of the toxicity is excreted by the kidney; hence, it exerts deleterious toxic effects through several mechanisms. Since urea is the end product of protein metabolism, the fenvalerate causes an increase in tubular permeability, leading to a decrease in the glomerular filtration rate. This causes decreased excretion and increased retention of nitrogenous wastes. The muscle contains the phosphocreatine, which undergoes spontaneous cyclization and forms creatinine which due to fenvalerate toxicity is severely affected and causes rise in the levels. Similarly, the proteins and albumin levels are also disrupted due to fenvalerate toxicity (Hohreiter et al., 1991 (Oreochromis mossambicus); Sun et al., 2007; Binukumari et al., 2016 (Labeo rohita); Brander et al., 2016 (vertebrates); Manavi et al., 2018; Vieira and Dos Reis Martinez, 2018 (Prochilodus lineatus); Velmurugan et al., 2018 (Oreochromis mossambicus); Pico et al., 2019 (freshwater fish)). After the administration of ascorbic acid, there was a significant restoration in the biochemical levels denotes the antioxidant and antitoxic effect of it. Furthermore, ascorbic acid also controls the metabolic function through various pathways (Datta and Kaviraj 2003; Bhattacharya and Kaviraj 2009).

Besides, there was significant damage at the cellular level in different doses of fenvalerate exposed fish. The kidney tissue was severely damaged as the Bowman's capsule, glomerulus, the convoluted tubules. But, after the administration of ascorbic acid, there was a significant restoration in the kidney tissue. The antioxidant activity of ascorbic acid has caused restoration at the cellular level. Furthermore, the ascorbic acid also enhances the immune system of the fish, which helps to control the toxic effect of the pesticide. Various researchers have correlated the effect on other pesticides (chlorpyrifos) and heavy metals (cadmium) effect (Kumari and Sahoo 2005; Kumar et al. 2009; Narra et al., 2015; Narra 2017).

Hence, fenvalerate caused the deleterious effect to the fish at the biochemical level and histopathological level. Ascorbic acid plays a vital role to control the fenvalerate induced toxicity; hence, it possesses the nephroprotective effect.

\section{Conclusion}

The kidney function tests such as serum urea, creatinine, protein and albumin level of the fish increased due to fenvalerate induced toxicity. In addition to it, the normal architecture of histology of Bowman's capsule, convoluted tubules and distal tubules of kidney were disrupted due to intoxication of the pesticide in the fish. Ascorbic acid played a key role to combat the 
Jigyasu, S. K. and Paul, D.K. / J. Appl. \& Nat. Sci. 12(3): 380 - 387 (2020)

fenvalerate induced nephrotoxicity in the freshwater fish $C$. batrachus. Hence it can be used to enhance the immune system of fish health, which will be beneficial to mankind.

\section{REFERENCES}

1. Awad, E., and Awaad, A. (2017). Role of medicinal plants on growth performance and immune status in fish. Fish Shellfish Immunol. 67, 40-54. https://doi.org/10.1016/j.fs i.2017.05.034.

2. Awoyemi, O. M., Kumar, N., Schmitt, C., Subbiah, S., and Crago, J. (2019). Behavioral, molecular and physiological responses of embryo-larval zebrafish exposed to types I and II pyrethroids. Chemosphere. 219: 526-537. doi: 10.1016/j.chemosphere.2018.12.026.

3. Berthelot, M.P.E. (1859). Berthelot's Reaction Mechanism. Report de Chimie Applique, 2884.

4. Bhattacharya, M., and Kaviraj, A. (2009). Toxicity of the pyrethroid pesticide fenvalerate to freshwater catfish Clarias gariepinus: Lethality, biochemical effects and role of dietary ascorbic acid. Journal of Environmental Science and Health, 44(6), 578-583. https://doi:10.10 80/03601230903000602.

5. Binukumari, S., Devi, K. A., and Vasanthi, J. (2016). Applications in environmental risk assessment of biochemical analysis on the Indian freshwater fish, Labeo rohita exposed to monocrotophos pesticide. Environmental Toxicology and Pharmacology, 47,:200-205. https://doi.org/1 0.1016/j.etap.2016.08.014.

6. Bojarski, B., and Witeska, M. (2020). Blood biomarkers of herbicide, insecticide, and fungicide toxicity to fish -a review. Environmental Science and Pollution Research, 115. https://doi.org/10.1007/s11356-020-08248-8.

7. Bonsnes, R. W. and Taussky, H.H. (1945). On the colorimetric determination of creatinine by Jaffee reaction. Journal of Biological Chemistry, 158: 581-591.

8. Brander, S.M., Gabler, M.K., Fowler, N.L., Connon, R.E., and Schlenk, D. (2016). Pyrethroid pesticides as endocrine disruptors: Molecular mechanisms in vertebrates with a focus on fishes. Environmental Science \& Technology, 50(17), 8977-8992. https://doi:10.1021/acs.est.6b 02253.

9. Bretschneider, T., Fischer, R., and Nauen, R. (2007). Inhibitors of lipid synthesis (acetyl-CoA-carboxylase inhibitors). Modern Crop Protection Compounds, 3: 909-926.

10.Clark, J. M., and Matsumura, F. (1982). Two different types of inhibitory effects of pyrethroids on nerve $\mathrm{Ca}$ and $\mathrm{Ca}+$ Mg-ATPase activity in the squid, Loligo pealei. Pesticide Biochemistry and Physiology, 18(2): 180 -190 .

11.Clasen, B., Loro, V. L., Murussi, C. R., Tiecher, T. L., Moraes, B., and Zanella, R. (2018). Bioaccumulation and oxidative stress caused by pesticides in Cyprinus carpio reared in a rice-fish system. Science of the Total Environment, 626: 737-743. https://doi.org/10.1016/j.scitote nv.20 18.01.154.

12.Coats, J. R., Symonik, D. M., Bradbury, S. P., Dyer, S. D., Timson, L. K., and Atchison, G. J. (1989). Toxicology of synthetic pyrethroids in aquatic organisms: an overview. Environmental Toxicology and Chemistry: An International Journal, 8(8): 671-679.
13.Cole, L. M., Lawrence, L. J., and Casida, J. E. (1984). Similar properties of [35S] t-butyl bicyclophosphorothionate receptor and coupled components of the GABA receptor-ionophore complex in brains of human, cow, rat, chicken and fish. Life Sciences, 35(17), 17551762. https://doi.org/10.1016/0024-3205(84)90272-8.

14.Datta, M. and Kaviraj, A. (2003). Ascorbic acid supplementation of diet for reduction of deltamethrin induced stress in freshwater catfish Clarias gariepinus. Chemosphere, 53, 883-888.

15.Datta-Mitra, A., and Ahmed Jr, O. (2014). Ayurvedic medicine use and lead poisoning in a child: A continued concern in the United States. Clinical Pediatrics, 54(7) 690692. https://doi.org/10.1177/0009922814553397.

16.Doumas, B.T., Watson, W.A., and Biggs, H.G. (1971). Albumin standards and the measurement of serum albumin with bromcresol green. Clinica Chimica Acta, 31(1):87 -96. https://doi:10.1016/0009-8981(71)90365-2.

17.Eells, J. T., Rasmussen, J. L., Bandettini, P. A., and Propp, J. M. (1993). Differences in the neuroexcitatory actions of pyrethroid insecticides and sodium channelspecific neurotoxins in rat and trout brain synaptosomes. Toxicology and Applied Pharmacology, 123(1): 107-119. https://doi.org/10.1006/taap.1993.1227.

18.Elbert, A., Brück, E., Melgarejo, J., Schnorbach, H. J., and Sone, S. (2005). Field development of Oberon® for whitefly and mite control in vegetables, cotton, corn, strawberries, ornamentals and tea. PflanzenschutzNachrichten Bayer, 58(3): 441-468.

19.Fujimoto, R. Y., Santos, R. F., and Carneiro, D. J. (2013). Morphological deformities in the osseous structure in spotted sorubim Pseudoplatystoma coruscans (Agassiz \& Spix, 1829) with vitamin C deficiency. Anais da Academia Brasileira de Ciências, 85(1), 379-384. https://doi:10.15 90/s0001-37652013005000022.

20.Gamble, M. (2008). The hematoxylin and eosin. In: Bancroft JD, Gamble M, editors. Theory and practice of histological techniques. 6th ed. London (UK): Churchill Livingston/Elsevier Inc. p. 121-134.

21.Gornall, A. G., Bardawill, C. J., and David, M. M. (1949) Determination of serum proteins by means of the biuret reaction. Journal of Biological Chemistry. 177(2), 751-766.

22.Hohreiter, D. W., Reinert, R. E., and Bush, P. B. (1991). Effects of the insecticides carbofuran and fenvalerate on adenylate parameters in bluegill sunfish (Lepomis macrochirus). Archives of Environmental Contamination and Toxicology, 21(3): 325-331. https://doi:10.1007/BF010 60353.

23.Hu, L., Luo, D., Zhou, T., Tao, Y., Feng, J., and Mei, S. (2017). The association between non-Hodgkin lymphoma and organophosphate pesticides exposure: A metaanalysis. Environmental Pollution, 231(Pt1), $319 \square 328$. doi: https://doi.org/10.1016/j.envpol.2017.08.028 .

24.Jigyasu, S. K. and Paul, D. K. (2016). Renatosomatic index of a freshwater fish intoxicated with pyrethroid pesticide. Nature Environment and Toxicology.15 (3),963-965.

25.Katagi, T. (2010). Bioconcentration, bioaccumulation, and metabolism of pesticides in aquatic organisms. Reviews of Environmental Contamination and Toxicology, 204: 1132. Springer, New York, NY. https://doi.org/10.1007/9781-4419-1440-8_1. 
26.Kumar, P., Prasad, Y., Patra, A. K., Ranjan, R., Swarup, D., Patra, R. C., and Pal, S. (2009). Ascorbic acid, garlic extract and taurine alleviate cadmium-induced oxidative stress in freshwater catfish (Clarias batrachus). Science of the Total Environment, 407(18): 5024 $\square$ 5030. https:// doi:10.1016/j.scitotenv.2009.05.030.

27.Kumari, J., and Sahoo, P. K. (2005). High dietary vitamin $C$ affects growth, non-specific immune responses and disease resistance in Asian catfish, Clarias batrachus. Molecular and Cellular Biochemistry, 280(1-2): 25 33. https://doi:10.1007/s11010-005-8011-z.

28.Lee, P. W., Stearns, S. M., and Powell, W. R. (1985). Rat metabolism of fenvalerate (Pydrin insecticide). Journal of Agricultural and Food Chemistry, 33(5): 988-993.

29.Ma, Y., Chen, L., Lu, X., Chu, H., Xu, C., and Liu, W. (2009). Enantioselectivity in aquatic toxicity of synthetic pyrethroid insecticide fenvalerate. Ecotoxicology and Environmental Safety. 72(7),1913 $\square$ 1918. https:// doi:10.1016/j.ecoenv.2009.07.005.

30.Matsumura, F. (1983). Influence of chlorinated and pyrethroid insecticides on cellular calcium regulatory mechanisms. In: Miyamoto J, Kearney JC (eds) Mode of action, metabolism and toxicology, vol 3. Pesticide Chemistry: Human Welfare and the Environment. Pergamon Press, NY, pp 3-13.

31.Merlevede, E. (1950). La vitamine C comme antidote des hydrocarbures aromatiques [Vitamin $\mathrm{C}$ as antidote for aromatic hydrocarbons]. Acta medicinae legalis et socialis, 3(1): $27 \square 31$.

32.Mojiri, A., Zhou, J. L., Robinson, B., Ohashi, A., Ozaki, N., Kindaichi, T., and Vakili, M. (2020). Pesticides in aquatic environments and their removal by adsorption methods. Chemosphere, 126646. https://doi.org/10.1016/ j.chemosphere.2020.126646.

33.Narahashi, T. (1983). Nerve membrane sodium channels as the major target site of pyrethroids and DDT insecticides, toxicity. In Pesticide Chemistry: human welfare and the environment: Proceedings of the 5th International Congress of Pesticide Chemistry, Kyoto, Japan, (Eds., J. Miyamoto and P.C. Kearney). Oxford : Pergamon Press, pp: 109-114.

34.Narra, M. R., Rajender, K., Rudra, R. R., Rao, J. V., and Begum, G. (2015). The role of vitamin $C$ as antioxidant in protection of biochemical and haematological stress induced by chlorpyrifos in freshwater fish Clarias batrachus. Chemosphere, 132:172-178. https://doi:10.1016/ j.chemosphere.2015.03.006.

35.Narra, M. R. 2017. Haematological and immune upshots in Clarias batrachus exposed to dimethoate and defying response of dietary ascorbic acid. Chemosphere, 168: 988-995. https://doi:10.1016/j.chemosphere.2016.10.112.

36. Manavi, P. N., Mahdavi, E. S., and Mazumder, A. (2018). Organochlorine pesticides in two fish species from the southern Caspian Sea. Marine Pollution Bulletin, 133: 289-293. https://doi.org/10.1016/j.marpolbu I.2018.05.05

37.Nhu, T. Q., Bich Hang, B. T., Vinikas, A., Bach, L. T., Buu Hue, B. T., Thanh Huong, D. T., Quetin-Leclercq, J., Scippo, M. L., Phuong, N. T., and Kestemont, P. (2019). Screening of immuno-modulatory potential of different herbal plant extracts using striped catfish
(Pangasianodon hypophthalmus) leukocyte-based in vitro tests. Fish \& Shellfish Immunology, 93: 296-307. https:// doi.org/10.101 6/j.fsi.2019.07.064.

38.Pico, Y., Belenguer, V., Corcellas, C., Diaz-Cruz, M. S., Eljarrat, E., Farré, M., and Barcelo, D. (2019). Contaminants of emerging concern in freshwater fish from four Spanish Rivers. Science of the Total Environment, 659: 1186-1198. https://doi.org/10.1016/j.scitotenv.2018.12.36 6.

39.Ramesh, M., Sankaran, M., Veera-Gowtham, V., and Poopal, R. K. (2014). Hematological, biochemical and enzymological responses in an Indian major carp Labeo rohita induced by sublethal concentration of waterborne selenite exposure. Chemico-biological Interactions, 207: 67-73. https://doi.org/10.1016/j.cbi.2013.10.018.

40.Sabarwal, A., Kumar, K., and Singh, R. P. (2018). Hazardous effects of chemical pesticides on human healthCancer and other associated disorders. Environmental Toxicology and Pharmacology,63:103-114. https:// doi:10.1016/j.etap.2018.08.018.

41.Sharma, G., and Singh, S. (2004). Studies on the effect of intoxicant indofil on the blood morphology of Channa punctatus (Bloch.). Bionotes, 6(1): 20.

42.Sharma, G., and Singh, S. (2006). Assay of some blood parameters of the fish, Channa punctatus (Bloch.) after intoxication of indofil. Bionotes, 8(1): 21.

43.Sun, H., Xu, XL., Xu, LC., Song, L., Hong, X., Chen, JF., Cui, LB., and Wang, XR. (2007). Antiandrogenic activity of pyrethroid pesticides and their metabolite in reporter gene assay. Chemosphere, 66(3): 474-479. https://doi:10.1016/j.chemosphere.2006.05.059.

44.Tripathi, G. (1992). Relative toxicity of aldrin, fenvalerate, captan and diazinon to the freshwater food-fish, Clarias batrachus. Biomedical and Environmental Sciences, 5(1): 33-38.

45.Tripathi, G., and Verma, P. (2004). Fenvalerate-induced changes in a catfish, Clarias batrachus: metabolic enzymes, RNA and protein. Comparative Biochemistry and Physiology. Part C: Toxicology \& Pharmacology. 138(1): 75-79. https://doi.org/10.1016/j.cca.2004.05.005.

46.Vale, J. A., and Kulig, K. (2004). American Academy of Clinical Toxicology; European Association of Poisons Centres and Clinical Toxicologists "Position paper: gastric lavage". Journal of Toxicology: Clinical Toxicology, 42 (7): 933-943. https://doi:10.1081/CLT-200045006.

47.Vallejos-Vidal, E., Reyes-López, F., Teles, M., and MacKenzie, S. (2016). The response of fish to immunostimulant diets. Fish \& Shellfish Immunology. 56:34-69. https:// doi.org/10.1016/j.fsi.2016.06.028.

48.Velmurugan, B., Selvanayagam, M., Cengiz, E. I., and Unlu, E. (2007). The effects of fenvalerate on different tissues of freshwater fish Cirrhinus mrigala. Journal of Environmental Science and Health, Part B. 42(2):157-163. https://doi:10.1080/03601230601123292.

49.Velmurugan, B., Senthilkumaar, P., and Karthikeyan, S. (2018). Toxicity impact of fenvalerate on the gill tissue of Oreochromis mossambicus with respect to biochemical changes utilizing FTIR and principal component analysis. Journal of Biological Physics, 44(3): 301-315. https:// doi:10.1007/s10867-018-9484-9.

50.Vieira, C., and Dos Reis Martinez, C. B. (2018). The pyrethroid $\lambda$-cyhalothrin induces biochemical, genotoxic, and 
Jigyasu, S. K. and Paul, D.K. / J. Appl. \& Nat. Sci. 12(3): 380 - 387 (2020)

physiological alterations in the teleost Prochilodus lineatus. Chemosphere, 210: 958-967.

51.Woo, S. J., Kim, N. Y., Kim, S. H., Ahn, S. J., Seo, J. S., Jung, S. H., Cho, M. Y., and Chung, J. K. (2018). Toxicological effects of trichlorfon on hematological and biochemical parameters in Cyprinus carpio L. following thermal stress. Comparative Biochemistry and Physiology. Toxicology \& Pharmacology. 209: 18-27. https:// doi.org/10.1016/j.cbpc.2018.03.001.

52.Yang, C., Lim, W., \& Song, G. (2020). Mediation of oxida- tive stress toxicity induced by pyrethroid pesticides in fish. Comparative Biochemistry and Physiology. Toxicology \& Pharmacology, 234: 108758. https://doi.org/10.1016/ j.cbpc.2020.108758.

53.Zhang, Q., Zhang, Y., Du, J., and Zhao, M. (2017). Environmentally relevant levels of $\lambda$-cyhalothrin, fenvalerate, and permethrin cause developmental toxicity and disrupt endocrine system in zebrafish (Danio rerio) embryo. Chemosphere, 185: 1173-1180.https://doi:10.1016/ j.chemosphere.2017.07.091. 